\title{
Ultrastructural Observations of the Vitelline Cells of Metamicrocotyla macracantha (Monogenea, Microcotylidae)
}

\author{
Maria de Fatima D Baptista-Farias ${ }^{+}$, Anna Kohn*
}

Laboratório de Helmintos Parasitos de Peixes, Departamento de Helmintologia, Instituto Oswaldo Cruz, Av. Brasil 4365, 21045-900 Rio de Janeiro, RJ, Brasil

An electron microscopic study of the vitelline follicles of Metamicrocotyla macracantha (Alexander, 1954) Koratha,1955 showed that they are composed of cells in different stages of development. The immature cells have a large nucleus, nucleolus, cytoplasm with free ribosomes and few mitochondria. The developing vitelline cells present granules which are small in the early stages, increasing with maturity. The mature cells have an extensive granular endoplasmic reticulum and droplets of shellprotein; with maturation, clusters of shell protein and yolk bodies are formed and released in the ciliated vitelline ducts. Vitelline development is continuous and all of the cellular stages involved can be found in each follicle.

Key words: Metamicrocotyla macracantha - ultrastructure - vitelline cells - Monogenea - Microcotylidae

In the light of the review of the literature on the ultrastructure of the Monogenea, published by Justine in 1993, many studies have been made on spermatogenesis and spermiogenesis but only a few on vitellogenesis (Halton et al. 1974, Ramalingan 1976, Cable \& Tinsley 1991). In contrast, there are many more reports on vitelline cells investigated in the Digenea (Irwin \& Threadgold 1970, Erasmus 1975, Irwin \& Maguire 1979, Holy \& Wittrock 1986, Hendow \& James 1989, Chaymardanov \& Tanyuksel 1995).

The morphology of Metamicrocotyla macracantha (Alexander, 1954) Koratha, 1955 was studied by light and scanning electron microscopy by Kohn et al. (1994), and the nature of the sperm and spermatogenesis in this worm by BaptistaFarias et al. (1995). The present study details ultrastructural observations of the vitelline cells of this microcotylid monogenean parasite.

\section{MATERIALS AND METHODS}

The parasites were collected from the gills of Mugil liza from the coast of Rio de Janeiro, Brazil, following examination in a saline medium under stereoscopic microscope. For light microscopy,

\footnotetext{
${ }^{+}$Corresponding author. Fax: +55-21-260.4866/ 590.3545. E-mail: bfarias@gene.dbbm.fiocruz.br *Research fellow I-A from "Conselho Nacional de Desenvolvimento Científico e Tecnológico - CNPq", Brazil.

Received 26 November 1997

Accepted 15 May 1998
}

worms were fixed in 5\% formalin under slight cover-slip pressure and stained in alcoholic chlorhydric carmine (Langeron 1949), dehydrated through an alcohol series, cleared in beechwood creosote and mounted in Canada balsam. For transmission electron microscopy, worms were fixed in $0.1 \mathrm{M}$ phosphate-buffered $2.5 \%$ glutaraldehyde, post-fixed for $1 \mathrm{hr}$ in $1 \%$ osmium tetroxyde in the same buffer, dehydrated in an increasing graded ethanol series and embedded in epon (Luft 1961). Sections $(0.5 \mu \mathrm{m}$ thickness) were stained with toluidine blue and observed under light microscope. Ultrathin sections were collected on copper grids, double-stained with $2 \%$ alcoholic uranyl acetate and lead citrate (Reynolds 1963) and examined with a Zeiss EM 900 electron microscope.

\section{RESULTS}

By light microscopy, the vitelline cells of $M$. macracantha are seen to be composed of numerous follicles, occupying almost all of the parasite's body. They extend from the caecal bifurcation to the anterior region of the pseudo-sucker. Each vitelline follicle contains cells in various stages of development surrounded by a definite membrane. These cells vary in size from small immature cells through cells in development to larger mature cells (Fig. 1).

Observed by transmission electron microscopy, the vitelline follicles are juxtaposed, separated by profiles of parenchyma and small amounts of fibrous material and muscle fibers.

Immature vitelline cells are irregularly-shaped and each contains a large nucleus which occupies 
almost all the cellular volume, a single nucleolus, and dense areas of heterochromatin. The cytoplasm is filled with numerous unattached ribosomes and a few mitochondria with developed cristae and weakly-stained matrices (Fig. 2).

Vitelline cells in development are larger, have nuclei similar to the immature ones, cytoplasm with a Golgi apparatus and granular endoplasmatic reticulum (GER). At this stage, droplets of eggshell protein appear and the cytoplasm shows large amounts of the shell material, due to continuous protein synthesis (Figs 3, 4). During maturation, the vitelline cells increase in size and in the quantity of membrane-bounded protein globules that form clusters (Figs 5, 6). In the mature cells, the amount of heterochromatin decreases in the
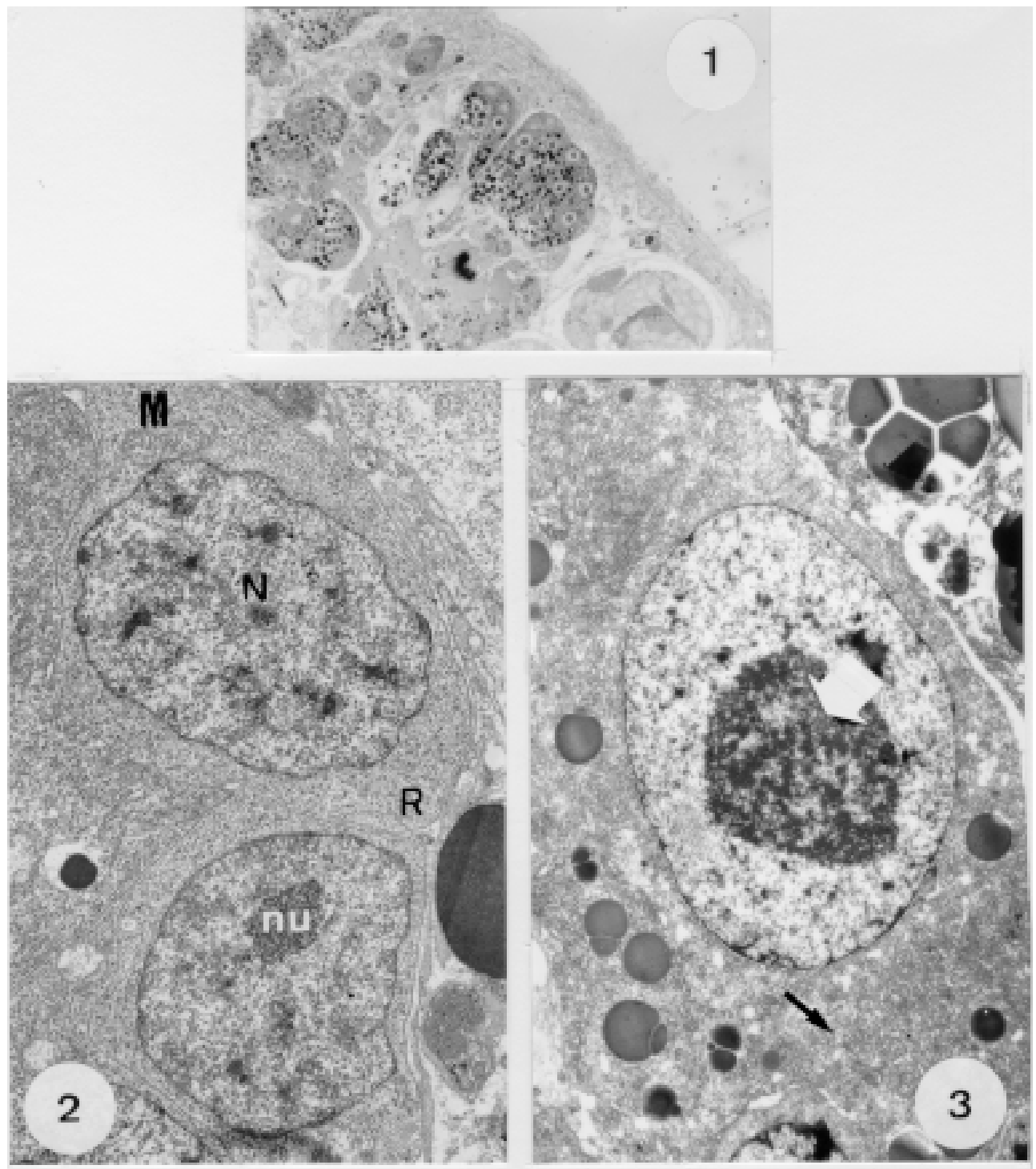

Metamicrocotyla macracantha. Fig. 1: transverse section of vitelline follicles showing the various stages of vitelline cell development. X 20. Fig. 2: immature cells of the vitelline follicles, with a large nucleus (N), nucleolus (nu), mitochondria (M) and free ribosomes (R). X 6,000. Fig. 3: developing vitelline cell with nucleus, large nucleolus (arrow), granular endoplasm reticulum (litlle arrow) and droplets of egg shell-protein. X 9,000. 

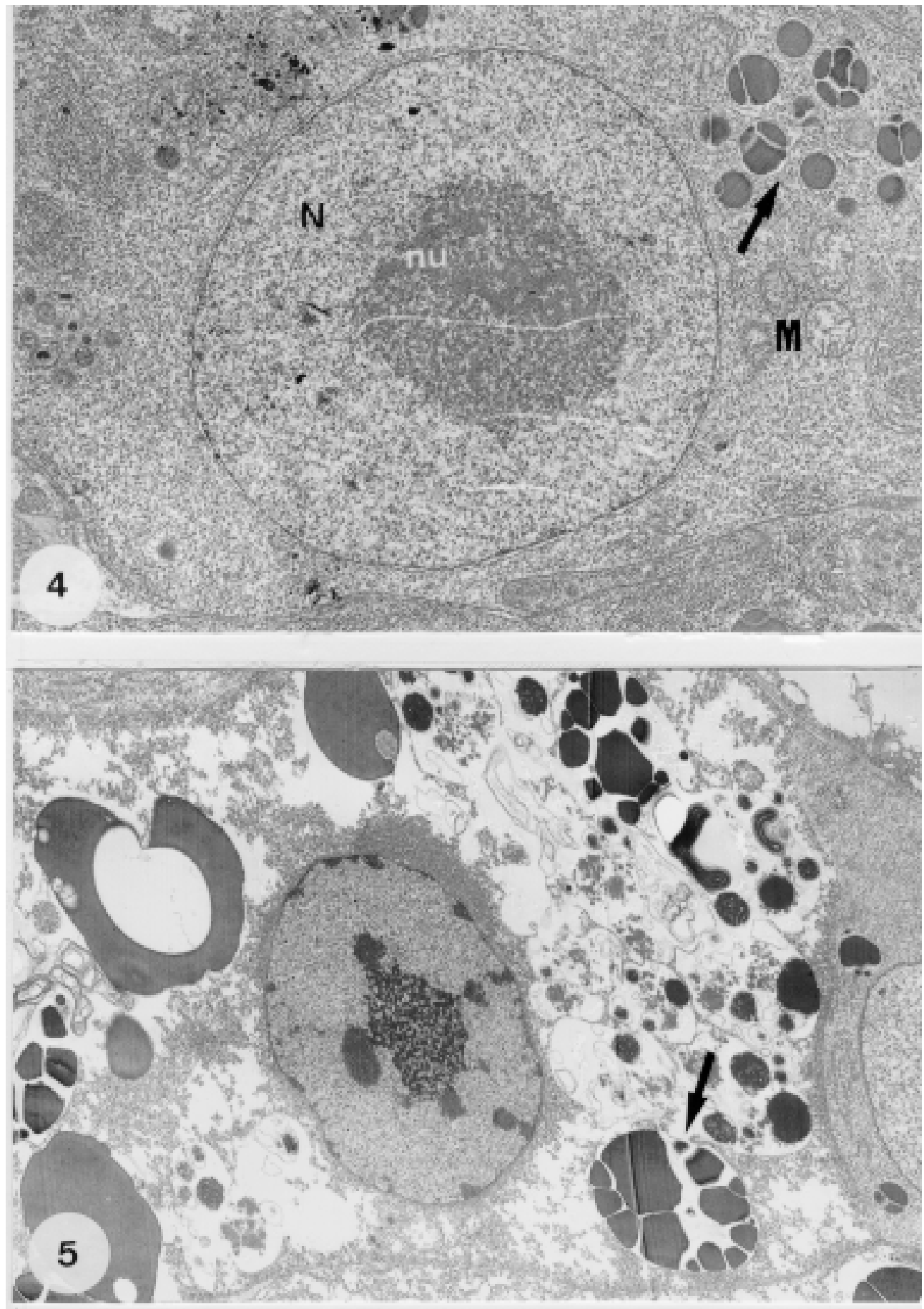

Metamicrocotyla macracantha. Fig. 4: part of a developing vitelline cell at higher magnification, showing the nucleus (N), nucleolus (nu), droplets of egg shell-protein being formed (arrow), and a few mitochondria (M). X 11,000. Fig. 5: mature vitelline cell showing the increase of the shell-protein droplets (arrow) and the decrease of the nuclear heterochromatin. X 7,000. 

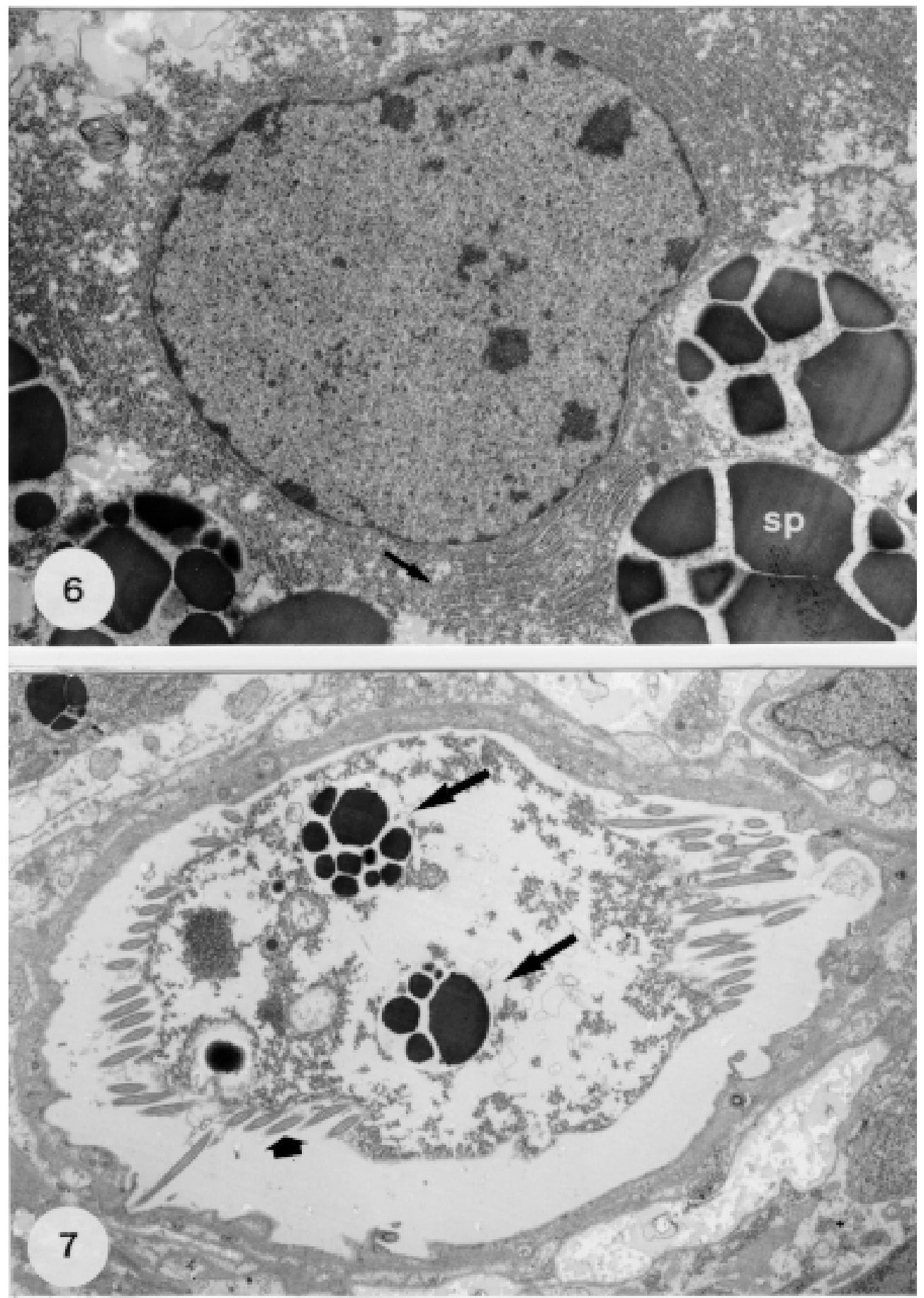

Metamicrocotyla macracantha. Fig. 6: detail of a mature cell with nucleus, the parallel arrays of granular endoplasm reticulum (arrow) and the droplets of membrane-bounded shell-protein (SP). X 13,000. Fig. 7: transverse section of a ciliated (large arrows) vitelline duct with droplets of shell-protein (arrows) released by the cells. X 6,400. 
nucleus, while the nucleolus increases in size. This stage is characterized by a growing number of eggshell droplets while the cells are at a high level of active secretion. The mature cells can be found isolated or in groups, directed toward the lumen of the vitelline ducts.

At the end of the development, the vitelline cell cytoplasm is filled with parallel arrays of GER and homogeneous droplets of shell-protein that gradually increase in size, alongside deposits of lipid and glycogen which, with disintegrated portions of GER form into large "yolk bodies". All of these inclusions can be observed as isolated components or in groups, throughout the cytoplasm, in variable number, or present and largely free in the ciliated vitelline ducts ready to be expelled (Figs $5,6,7)$.

\section{DISCUSSION}

Halton et al. (1974) published a histochemical and electron microscopic study of the vitellaria of three polyopisthocotylean fish-gill flukes, Diplozoon paradoxum, Diclidophora merlangi and $D$. denticulata, demonstrating that the vitelline cell development is basically similar in these species. The vitelline cell development of $M$. macracantha is similar to that of these polyopisthocotyleans. The ultrastructural evidence on vitelline cell development is also similar to that of Digenea such as: Fasciola hepatica, studied by Irwin and Threadgold (1970), Schistosoma mansoni by Erasmus (1973), Gorgoderina vitelliloba by Irwin and Maguire (1979), Halipegus eccentricus by Holy and Wittrock (1986) and Maritrema linguilla by Hendow and James (1989).

The immature vitelline cells of $M$. macracantha have a large nucleus, nucleolus, cytoplasm with free ribosomes and mitochondria. The developing vitelline cells show granules which are small in the early stages, but which increase with maturity. The structural differences among the vitelline cells are connected with an increase in the synthesis of egg-shell granules. The maturation of the vitelline cells involves an increase in the amount of the cytoplasm accompanied by the development of GER, derived from the nuclear envelope, and which characterizes a secretory activity. At the end of the development, the cytoplasm of the vitelline cells is filled with droplets of shell-protein, with a decrease in the populations of ribosomes. This is due to the change of the function of these cells from protein synthesis to food storage.

The increase in cell size, synthesis of shell-protein, formation of yolk and deposition of glycogen and lipid is common to other parasites. Immature vitelline cells occur predominantly at the periphery of the follicles and progressively mature towards the center, where, complete with egg-shell protein globules and yolk, they break free and pass into the vitelline ducts (Irwin \& Threadgold 1970).

According to Halton et al. (1974), all of these processes can be found in all of the follicles at the same time, and all stages of maturation take place in any follicle.

\section{ACKNOWLEDGEMENTS}

To Dr David W Halton from the Queens University of Belfast, UK, for his critical review of the manuscript. To Dr Monika Barth from Departamento de Virologia, Instituto Oswaldo Cruz, for the facilities offered for the use of the electron microscope.

\section{REFERENCES}

Baptista-Farias MFD, Kohn A, Barth OM 1995. Ultrastructural aspects of spermatogenesis in Metamicrocotyla macracantha (Alexander, 1954) Koratha, 1955 (Monogenea; Microcotylidae). Mem Inst Oswaldo Cruz 90: 597-604

Cable J, Tinsley RC 1991. Intra-uterine larval development of the polystomatid monogeneans, Pseudodiplorchis americanus and Neodiplorchis scaphiopodis. Parasitology 103: 253-266.

Chaymardanov JK, Tanyuksel M 1995. Morphological and histochemical observations on the vitelline cells of adult Dicrocoelium dendriticum. Tr J Zool 19: 323-329.

Erasmus DA 1973. A comparative study of the reproductive system of mature, immature and "unisexual" female Schistosoma mansoni. Parasitology 67: 165183.

Erasmus DA 1975. The subcellular localization of labelled tyrosine in the vitelline cells of Schistosoma mansoni. Z Parasitenk 46: 75-81.

Halton DW, Stranock SD, Hardcastle A 1974. Vitelline cell development in monogenean parasites. $Z$ Parasitenk 45: 45-61.

Hendow HT, James BL 1989. Ultrastructure of vitellarium, vitellogenesis and associated ducts in Maritrema linguilla (Digenea:Microphallidae). Int Parasitol 19: 489-497.

Holy JM, Wittrock DD 1986. Ultrastructure of the female reproductive organs (ovary, vitellaria and Mehlis' gland) of Halipegus eccentricus (Trematoda: Derogenidae). Can J Zool 64: 2203-2212.

Irwin SW, Maguire JG 1979. Ultrastructure of the vitelline follicles of Gorgoderina vitelloba (Trematoda: Gorgoderidae). Int J Parasitol 9: 47-53.

Irwin SW, Threadgold LT 1970. Electron microscope studies on Fasciola hepatica VIII. The development of the vitelline cells. Exper Parasitol 28: 399-411.

Justine JL 1993. Ultrastruture des monogènes: Listes des espèces et des organes étudiés. Bull Fr Pêche Piscic 328: 156-188.

Kohn A, Cohen SC, Baptista-Farias MFD 1994. A redescription of the morphology of Metamicrocotyla macracantha (Alexander, 1954) Koratha, 1955 (Monogenea, Microcotylidae) from Mugil liza in Brazil. Syst Parasitol 27: 127-132. 
548 Vitelline Cells of M. macracantha - MFD Baptista-Farias, A Kohn

Langeron M 1949. Précis de Microscopie, 7th ed., Masson \& Cie, Paris, 1429 pp.

Luft JH 1961. Improvements in epoxi resin embedding methods. J Biophy Biochem Cytol 9: 409.

Ramalingan K 1976. Studies on vitelline cells of
Monogenea. I Morphology of vitelline cells of Pricea multae. Cytologia 41: 133-138.

Reynolds ES 1963. The use of lead citrate at high ph as electron opaque stain in electron microscopy. J Cell Biol 17: 208. 